\title{
AGRICULTURAL INSURANCE IN SERBIA: THE DEVELOPMENT AND DEVELOPING PERSPECTIVES
}

\section{Gordana Radović}

"Dnevnik-Poljoprivrednik" AD, Novi Sad, Serbia

\begin{abstract}
:
In accordance with the categorization done by the Organization for Economic Co-operation and Development (OECD), 85\% of the territory of the Republic of Serbia is considered rural. Agriculture in Serbia is of great economic and social importance, and therefore agricultural insurance should be developed as well, especially in the conditions when the climate changes are becoming even more marked. Agricultural production is considered high-risk. Apart from the production risks, agriculture is also exposed to institutional, financial and personal risks. Consequently, it is necessary to plan, organize, establish and develop an adequate risk management system in agriculture. Agricultural risk management system should be introduced in big companies as a segment of corporation management, as well as in small and medium agricultural companies, and agricultural households. When it comes to production management risks, or possible weather changes, insurance is definitely the best possible option. The aim of the study is to emphasize the significance of agricultural insurance in Serbia, analyze the current development and suggest a potential development model.
\end{abstract}

Keywords:

insurance, agriculture, development, Republic of Serbia.

\section{INTRODUCTION}

Agricultural insurance is one of the fastest growing insurance types in the world, and it is most developed in the USA and Canada, while Europe is only in the third place of development. Agricultural insurance was classified under the six priority groups of Common Agricultural Policy of the EU for the period from 2014 to 2020. Agricultural insurance is a kind of property insurance which comprises crop insurance, livestock insurance, and several special insurance subtypes that cover agricultural production hazards or only individual insurance subjects. The importance of agricultural insurance lies in the fact that it provides economic protection to its clients - farmers against harmful impacts and disturbances which may occur, i.e. when a foreseen insurance risk appears. Also, insurance funds can have a great financial potential which can be used for financing economic development, i.e. agricultural development. Therefore, it is clear that agricultural insurance, as well as financing, is an important condition for the development of this economic branch.

In accordance with the categorization by the Organization for Economic Co-operation and Development (OECD), 85\% of the territory of the Republic of Serbia is considered rural. According to the statistical data, cultivated agricultural land occupies 3.4 million hectares. The average contribution of agriculture, forestry and fishing in average gross value added to the national economy, as shown in current prices, was around $10 \%$ within the last decade. As for the external trade, i.e. export of goods, it was about $20 \%$. The percentage of rural population in the total population is about $40 \%$, while the participation of the employed in agriculture, forestry and fishing makes $20 \%$ of the overall number of employees in the state. These indicators clearly show that agriculture in Serbia has great economic and social importance, so the economic 
protection of agricultural production should be developed as well, especially bearing in mind ever increasing changes in the climate.

Agricultural production is considered high-risk. Apart from the production risks, agriculture is also exposed to institutional, financial and personal risks. Consequently, it is necessary to plan, organize, establish, and develop an adequate risk management system in agriculture. Agricultural risk management system should be introduced in big companies as a segment of corporation management, as well as in small and medium agricultural companies, and agricultural households. When it comes to production management risks, or possible weather changes, insurance is definitely the best possible option. The aim of the study is to emphasize the significance of agricultural insurance in Serbia, analyze the current development and suggest a potential development model.

\section{LITERATURE OVERVIEW}

There is a widespread opinion in the literature that crop insurance is one of the riskiest insurances. Consequently, economic protection in the market is only available for a limited number of risks. ${ }^{1}$ According to (Mishra, 1995) "agricultural insurance, especially crop insurance, is present in a lot of countries as an answer from the institutions to the current risks following agricultural production". ${ }^{2}$ In the current global context, as stated by (Iturrioz, 2009), crop insurance makes $90 \%$ of the total agricultural insurance premium. ${ }^{3}$ However, in recent years, due to cases of new animal diseases, livestock insurance is very much in demand.

Due to specific nature of agricultural insurance, complexity and high administrative costs, as well as significant risks accompanying agricultural production and often causing enormous damages, and climate changes, there is an almost unanimous point of view in the literature that this kind of insurance has to be managed with the help of the state and with its intervention. This action is most commonly done through subventions for insurance premium. ${ }^{4}$ According to (Mahul and Stutley, 2010), one of the most important issues in the policy of establishing agricultural insurance is the quality of being optional, i.e. it being compulsory. The quoted authors argue that the current data imply in what ways the optional policy is mostly in use, but states find ways of indirectly encouraging farmers to buy insurance policies. ${ }^{5}$

1 Petrevska, M, Toscano, B, Milošev, D. (2010). Osiguranje biljne proizvodnje, Beograd, 1.

2 Mishra, P. K. (1995). Is Rainfall Insurance a New Idea? Pioneering Work Revisited, Published by: Economic and Political Weekly, Vol. 30, No. 25, p. A86.

3 Iturrioz, R. (2009). Agricultural Insurance, Example Series on Insurance, Washington, DC, 11.

4 Neves, C. de R. M, Fazendeiro, E. (2007). Governmental Support to the agricultural insurance a parallel between Spain and USA, Brazilian Magazine of Risks and Insurance, Rio de Janeiro, Funenseg, Vol. 2, No. 4/2007, 57.
Generally, on the global level there is a direct connection between the state involvement and the level of developmentin agricultural crop insurance. ${ }^{6}$

Antonije Tasic, the first insurance theorist in these areas, stresses in his analysis that "non development of agricultural insurance present in our country is revealing the ultimate deterioration in our agriculture". ${ }^{7}$ According to him, the basic cause of deterioration in agricultural and economic protection development is the discrepancy in the prices of agricultural and industrial products in the Yugoslavian market.

\section{METHODOLOGY}

The subject of the research is the analysis of the current agricultural insurance development in Serbia. The basic hypothesis tested in the research claims the following: agricultural insurance in Serbia is not developed enough. We can observe current statistical data on the total cultivated agricultural land and the total number of registered agricultural households as the realistic development possibilities. The study uses empirical, inductive-deductive methods, a method of analysis and synthesis, comparative method and forecast method. What served as the data source were the reports by the National Bank of Serbia about the results of agricultural insurance in Serbia, together with data from the Ministry of Agriculture, Forestry and Water Management.

\section{RESULTS AND DISCUSSION}

This study analyses the agricultural insurance premium sizes and their participation in the overall premium of nonlife insurances in Serbia, as well as the number of agricultural households which use their right to insurance premium recourse. It is all done in order to estimate the current development of agricultural insurance in Serbia.

Information about the total agricultural insurance premiums, and about their fluctuations over the years, can be found on the National Bank of Serbia website. The comparative overview of the fluctuations in insurance premium for crop insurance and livestock insurance in Serbia during 2006-2016 is shown in chart number 1. Based on the information analysis, it can be concluded that crop insurance premiums in the set period have shown a significant, and (since 2009) a continuous increase. The total crop insurance premium reached its maximum in 2016, which is the last

5 Mahul, O, Stutley, C.J. (2010). Government Support to Agricultural Insurance Challenges and Options for Developing Countries, The World Bank, Washington, USA, 244.

6 Diaz-Caneja, M. B, Conte, C.G, Gallego-Pinilla, F.J, Stroblmair, J, Catenaro, R, Dittmann, C. (2009). Risk management and agricultural insurance schemes in Europe, JRC Reference Reports, European Commission, The Institute for the Protection of the Citizen, Ispra, VA, Italy, 28.

7 Tasić, A. (1994). Zaostalost poljoprivrednog osiguranja u osiromašenoj poljoprivredi, U: Zbirka rasprava i članaka iz osiguranja, Novi Sad, 121. 
year observed. The maximum was to the value of $1,847.1 \mathrm{mil}-$ lion Serbian dinars. However, even though the increase occurred, we still believe that the crop insurance is not developed enough, bearing in mind the available cultivated land, and relatively low insurance costs.

Chart 1. Comparative view of fluctuations of insurance premiums for plant production and livestock insurance in Serbia between 2006-2016 shown in (000) dinars

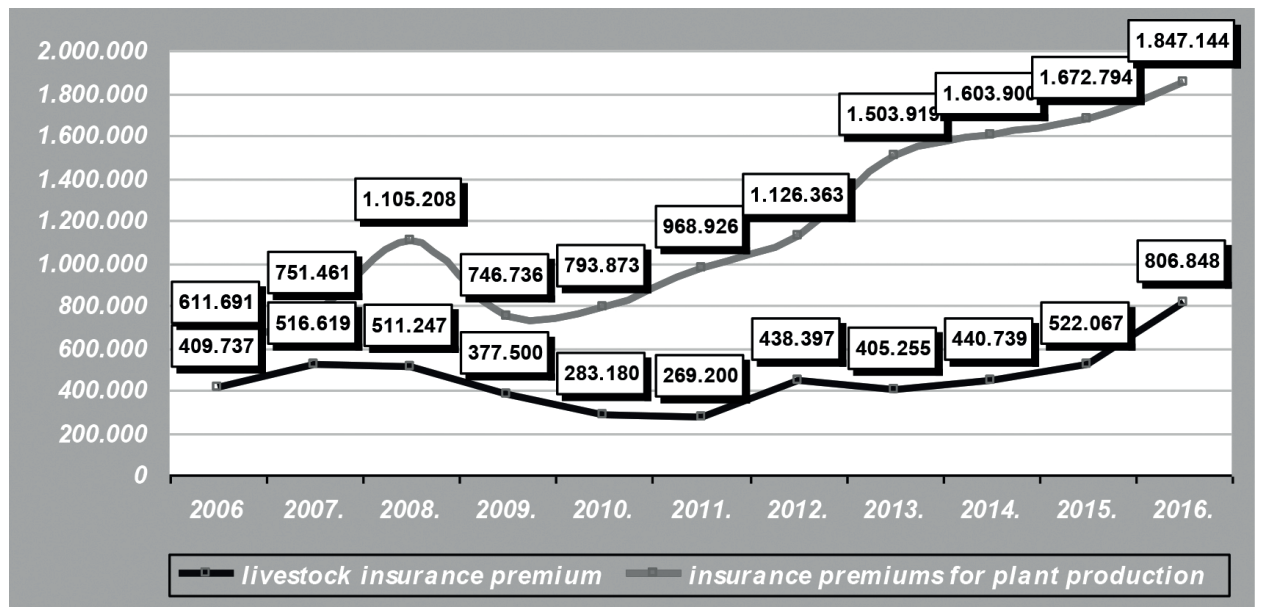

Source: http://www.nbs.rs/export/download/osg-izv-y/god_T1_2006-2016.pdf

By analyzing the fluctuation of the livestock insurance premium amounts in the observed decade (chart no.1), it can be concluded that there were significant oscillations in 2014, which marked the beginning of their growth. When comparing 2016 to 2015, the increase was 55\%, and it amounted to $97 \%$ compared to 2006 . The given data are favourable and they primarily come as a consequence of low starting sizes, but they also show the awareness of agricultural subjects of the importance of such insurance. The overall agriculture insurance premium for 2016 was 2,653,992 dinars, but that is merely $4.02 \%$ of the total non-life insurance in Serbia.

According to the information from insurance companies operating in Serbia, there were 407 thousand insured hectares of agricultural land in 2014. However, that makes only $8 \%$ of the total agricultural land, i.e. $15 \%$ of the total cultivated agricultural land in Serbia. ${ }^{8}$

The Ministry of Agriculture, Forestry and Water Management has been providing recourses for agricultural insurance premium since 2006. Since there is no such thing as a register of insured agricultural households in Serbia, the number of households that use their right to register insurance premiums can be used as information on the total number of insured agricultural households. The number of agricultural households that used their right to these subventions, from 2006 to 2016, is shown in chart number 2.

Upon analyzing the information shown in chart number 2 , it can be concluded that the number of agricultural

8 Radović, G. (2017). Osiguranje u funkciji razvoja poljoprivrede u Srbiji, Ekonomska politika u Srbiji u 2017. godini, Naučno društvo ekonomista Srbije i Akademija ekonomskih nauka, Beograd, 196. households that insure their production has been showing an increasing trend since 2013. Nevertheless, even though there were 20,112 insured agricultural households in 2016, the last year observed, which is the highest number of households during the whole period, that is only $3.18 \%$ of the whole number of agricultural households in Serbia. According to the agriculture census performed in 2012, the Republic of Serbia has 631,552 agricultural households in total. ${ }^{9}$ The complete amount of 580,220,156.22 dinars was paid off as a recourse to agricultural insurance premiums in 2016, and it represents $1.43 \%$ of the total agrarian budget for that year.

Based on the conducted research and analyses, while using the synthesis method, a conclusion can be drawn that agricultural insurance in Serbia, during the observed decade, was not developed enough, which proves the original assumption. We believe that the underdevelopment of agricultural insurance is closely connected to the underdevelopment in agricultural production. We also argue that it has been conditioned by the unfavorable economic position of agriculture in the national economic system during the last decades, i.e. during the whole period after the World War II. The underdevelopment of agricultural insurance in Serbia is also a consequence of insufficient education of farmers and their not being informed about the possibilities and importance of agricultural insurance. In order to develop agricultural insurance in Serbia, we need to discuss the prospective development options.

9 Strategy of Agriculture and Rural Development 2014-2024 (2015). Deutsche GesellschaftfürinternationaleZusammenarbeit (GIZ) GmbH, Bonn, Germany, 16. 
Chart 2. Number of agricultural households that used their right to recourse for agricultural insurance premium in the period $2006-2016$

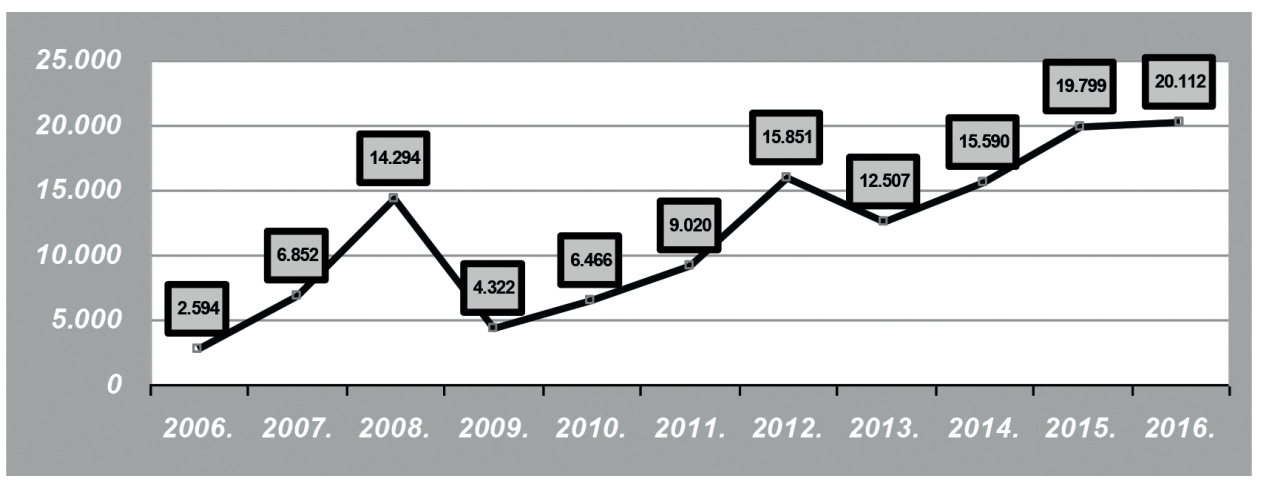

Source: The Ministry of Agriculture, Forestry and Water Management

\section{POTENTIAL MODEL FOR AGRICULTURAL INSURANCE DEVELOPMENT ${ }^{10}$}

A potential model for agricultural insurance in Serbia could be based on introducing a partly obligatory agricultural insurance. Because of that, it is necessary to legally define this insurance type as partly obligatory, and to adopt a strategy for agricultural insurance development in Serbia.

The proposed development mode, i.e. the model of partly obligatory agricultural insurance in Serbia implies obligatory agricultural insurance for all agricultural subjects that use a particular state resource. The insurance would cover the most usual risks that occur in a certain area. Therefore, based on the proposed model, agricultural insurance should be obligatory for users of encouragement resources for agricultural development that are taken from the republic, provincial or local management budgets. Also, it would be obligatory for users of loans that are provided by state institutions and which are granted with low (subvention) interest, as well as for those who are renting agricultural land that belongs to the state.

In the proposed development model, the obligatory agricultural insurance would include insurance against the risks that are most common in certain areas. Therefore, a map of agricultural risks should be made for Serbia similar to Croatia. The areas would then be divided according to the probability of occurrence of certain dangers, i.e. according to risk zones. That would also enable defining risk coefficients, together with obligatory agricultural insurance against the risks that are most common in certain areas.

Since the insurance companies' income would thus be increased, they should be directed towards financing agriculture, in accordance with the proposed model. Practically, insurance companies would be under the obligation to

10 Radović, G. (2016). Poljoprivredno osiguranje kao moguća vrsta obaveznog osiguranja u Republici Srbiji, Doktorska disertacija, Univerzitet „Džon Nezbit“, Beograd, Fakultet za poslovne studije, invest $20 \%$ of the charged agricultural insurance premium in financing agriculture, but they would not increase the price of the insurance. In our opinion, the funds would be most rationally used for agricultural financing if a specialized agricultural bank in Serbia was founded.

A specialized agricultural bank should be founded in the Republic of Serbia by introducing a necessary law, as a specialized (developing) financial state institution for the business. ${ }^{11}$ A specialized agricultural bank is supposed to give priority to the funds concerning preventive economic protection of agricultural subjects, in accordance with the proposed model for agricultural insurance development. The examples of economic protection are systems for irrigation and dewatering, setting up anti-hail constructions etc. Loans would be offered only to those subjects that are in the system of partly obligatory agricultural insurance and the conditions for this would be among the most favorable in the bank market.

Based on the suggested model of partly obligatory agricultural insurance, it is also necessary to introduce a state independent verification institution in the area of agricultural insurance in order to solve problems with regard to bad experience of agricultural subjects with certain insurance companies which occurred regarding estimation of the damage and the subsequent payment. Of course, it would also contribute to changing the negative attitude of agricultural subjects towards insurance.

\section{CONCLUSION}

The Republic of Serbia, as a mainly agrarian state, does not possess developed agriculture when compared to the resources it owns. Nondevelopment in agriculture affects the nondevelopment of agricultural insurance. In 2016, only $3.18 \%$ of the total number of agricultural households was

11 Radović, G. (2014). Finansiranje poljoprivrede u Republici Srbiji, Monografija, Beograd, 92-94. 
insured, and the contribution of agricultural insurance premium to the total premium of non-life insurance was only $4.02 \%$. The research data confirm the basic hypothesis that agricultural insurance in Serbia is not developed enough. Nondevelopment of agricultural insurance leads to consequences, i.e. it has a reflective effect on the nondevelopment of agriculture in Serbia.

In order to enable the desired development, the proposed model of partly obligatory agricultural insurance should be applied to Serbia. It implies that the insurance for all users of state agricultural resources should be mandatory. The increased income of insurance companies should be used (in accordance with the proposed model) for financing agriculture. To summarize, the application of the proposed model would enable the development of agricultural insurance, provide quality sources for agricultural financing, and develop this economic branch.

In order to adequately apply the proposed model of partly obligatory agricultural insurance to Serbia, it is necessary to promote continouous education and training of agricultural subjects. Also, a quality agricultural risk management system is needed, in which productions risks would only represent one part of it. Agricultural risk management system should be introduced in big companies as a segment of corporation management, as well as in small and medium-sized agricultural companies, and agricultural households. In order to create quality agricultural risk management, and adequate application of the proposed model to a partly obligatory agricultural insurance, it is necessary that the most common, i.e. the most frequent risks in Serbia are identified.

\section{LITERATURE}

Diaz-Caneja, M. B, Conte, C.G, Gallego-Pinilla, F.J, StrobImair, J, Catenaro, R, Dittmann, C. (2009). Risk management and agricultural insurance schemes in Europe, JRC Reference Reports, European Commission, The Institute for the Protection of the Citizen, Ispra, VA, Italy.

Iturrioz, R. (2009). Agricultural Insurance, Example Series on Insurance, Washington, DC, pp. 1-20.

Mahul, O, Stutley, C.J. (2010). Government Support to Agricultural Insurance Challenges and Options for Developing Countries, The World Bank, Washington, USA.

Mishra, P. K. (1995). Is Rainfall Insurance a New Idea? Pioneering Work Revisited, Published by: Economic and Political Weekly, Vol. 30, No. 25, pp. A84-A88. Available at: http:// www.jstor.org/stable/4402912.

Neves, C. de R. M, Fazendeiro, E. (2007). Governamental Support to the agricultural insurance a parallel between Spain and USA, Brazilian Magazine of Risks and Insurance, Rio de Janeiro, Funenseg, Vol. 2, No. 4/2007, pp. 51-74.

Petrevska, M, Toscano, B, Milošev, D, (2010). Osiguranje biljne proizvodnje, Beograd.

Priručnik za obuku za polaganje stručnog ispita za sticanje zvanja ovlašćenog posrednika i ovlašćenog zastupnika u osiguranju (2015). Privredna komora Srbije, Beograd.

Radović, G. (2014). Finansiranje poljoprivrede u Republici Srbiji, Monografija, Beograd.

Radović, G. (2016). Poljoprivredno osiguranje kao moguća vrsta obaveznog osiguranja u Republici Srbiji, Doktorska disertacija, Univerzitet „Džon Nezbit“, Beograd, Fakultet za poslovne studije, Beograd.

Radović, G. (2017). Osiguranje u funkciji razvoja poljoprivrede u Srbiji, Ekonomska politika u Srbiji u 2017. godini, Naučno društvo ekonomista Srbije i Akademija ekonomskih nauka, Beograd, str. 187- 204.

Strategija poljoprivrede i ruralnog razvoja 2014-2024 (2015). Deutsche Gesellschaft für internationale Zusammenarbeit (GIZ) GmbH, Bon, Nemačka.

Tasić, A. (1994). Zaostalost poljoprivrednog osiguranja u osiromašenoj poljoprivredi, U: Zbirka rasprava i članaka iz osiguranja, Novi Sad, 1994.

Narodna banka Srbije, http://www.nbs.rs, [Date of access: 16.09. 2017]. 